\section{Ameliorative Effects of Plant Growth Promoting Bacteria on Water-yield Relationships, Growth, and Nutrient Uptake of Lettuce Plants under Different Irrigation Levels}

\author{
Ustun Sahin \\ Department of Agricultural Structures and Irrigation, Faculty of Agriculture, \\ Atatürk University, Erzurum, Turkey \\ Melek Ekinci \\ Department of Horticulture, Faculty of Agriculture, Atatürk University, \\ Erzurum, Turkey
}

Fatih Mehmet Kiziloglu

Department of Agricultural Structures and Irrigation, Faculty of Agriculture, Atatürk University, Erzurum, Turkey

Ertan Yildirim ${ }^{1}$

Department of Horticulture, Faculty of Agriculture, Atatürk University, Erzurum, Turkey

\author{
Metin Turan \\ Department of Genetic and Bioengineering, Faculty of Engineering and \\ Architecture, Yeditepe University, Istanbul, Turkey
}

\section{Recep Kotan \\ Department of Plant Protection, Faculty of Agriculture, Atatürk University, Erzurum, Turkey}

\section{Selda Ors}

Department of Agricultural Structures and Irrigation, Faculty of Agriculture, Atatürk University, Erzurum, Turkey

Additional index words. lettuce, irrigation, growth, PGPR

\begin{abstract}
The aim of this study was to determine the effects of selected plant growthpromoting rhizobacteria (PGPR) on some physiological characteristics, plant growth, yield, and plant nutrient content of lettuce grown under different irrigation levels. Field experiments were carried out as split plot based on randomized complete block design with three replications. Three irrigation levels, $I_{1}=100 \%$ (control), $I_{2}=75 \%$, and $I_{3}=$ $50 \%$ of the field capacity (FC), were determined at the $0-15 \mathrm{~cm}$ soil depth by time-domain reflectometry (TDR), as main plots and three levels of bacterial species consisting of no bacterial inoculation (control), Bacillus megaterium TV 6D $\left(B_{1}\right)$, Bacillus subtilis TV $12 \mathrm{H}$ $\left(B_{2}\right)$ as sub plots in 2012 and 2013. Physiological characteristics, plant growth, yield, and plant nutrient content of lettuce was significantly affected by PGPR and irrigation quantities. Results showed that decreasing irrigation quantities significantly decreased the growth, dry and fresh head weight, and yield of lettuce in both years. Moreover, lower irrigation levels caused a decrease in leaf relative water content (LRWC), stomatal conductance (SC), and plant nutrient element content, but an increase electrolyte leakage (EL) and lipid peroxidation [malondialdehyde (MDA)]. However, PGPR inoculations significantly increased the growth, nutrient element content, LRWC, SC, and yield but decreased EL and MDA of lettuce plants grown under lower irrigation levels. The results of the study suggested that PGPR inoculations could alleviate the deleterious effects of lower irrigation conditions on the growth and yield of lettuce plants.
\end{abstract}

Water deficit is one of the main constraints affecting plant growth and crop yield in arid, semiarid, and even in humid areas, causing the fatal economic losses in agriculture (Marulanda et al., 2009; Sandhya et al., 2010). Drought has

been reported to affect various aspects of human lives of one-third of the world's population including human health and agricultural productivity. For example, according to an estimate by the United Nations, one-third of the world's population lives in areas where water is scarce. Furthermore, climatic changes also enhanced the frequency and intensity of water shortage in subtropical areas of Asia and Africa (Athar and Ashraf, 2009). Water deficit results in limitation to the plant growth and yield in agricultural crops. The decline of plant growth caused by water insufficiency is considered to be one of the most important ecological factors limiting plant survival and establishment (Henry and Le Hou'erou, 1996).

Plants are constantly exposed to a wide range of environmental stresses, which limit plant productivity. Over several centuries, breeding programs have focused on generating crop species with enhanced productivity under suboptimal environmental conditions (Saravanakumar et al., 2011). Drought resistance has been suggested as being a "complex trait," especially with the recent expansion of research into its genomics (Blum, 2011). Breeding of new crop varieties, screening, and selection of the existing germplasm of potential crops for mitigating the deleterious effects of drought stress have been suggested as major strategies. However, extent and rate of progress in improving stress tolerance in crops through conventional breeding program is limited. This is due to complex mechanism of abiotic stress tolerance, which is controlled by the expression of several minor genes. Furthermore, techniques employed for selecting tolerant plants are time consuming and consequently expensive (Athar and Ashraf, 2009). Therefore, improving methods and strategies to cope with deleterious effects of drought stress has received considerable attention nowadays. Recently, an alternative strategy to mitigate the harmful effects of water deficit on crops using PGPR has been suggested (Forchetti et al., 2010).

PGPR colonize the rhizosphere of plants and promote growth through various direct and indirect mechanisms (Glick, 1995). They have been suggested to ameliorate the growth of plants grown under environmental stress conditions, protecting plants from the deleterious effects of environmental stresses (Karlidag et al., 2011; Sandhya et al., 2010; Yildirim et al., 2006, 2008, 2011). The growthpromoting effect of PGPR may be mediated by reduction of stress ethylene production via the action of 1-aminocyclopropane-1-carboxylate (ACC) deaminase (Mayak et al., 2004); the synthesis of phytohormones such as indole3 -acetic acid (IAA), salicylic acid (SA), and gibberellin (GA) (Arkhipova et al., 2007; Forchetti et al., 2010; Turan et al., 2014); alleviation of the oxidative damage (Kohler et al., 2008); inducing changes in the expression of reactive oxygen species (ROS)-scavenging enzymes; and improved photosynthetic performance (Gururani et al., 2013). The term "induced systemic tolerance" has been proposed for PGPR-induced physical and chemical changes in plants that result in enhanced tolerance to abiotic stress (Yang et al., 2009). Furthermore, Pereyra et al. (2006) reported that PGPR inoculation could contribute to protect plants from 
drought stress through changes in the fatty acid distribution profiles of phosphatidylcholine and phosphatidylethanolamine major root phospholipids.

The PGPR have been reported to ameliorate the deleterious effects of drought stress on plant growth (Gururani et al., 2013; Heidari and Golpayegani, 2012; Marulanda et al., 2009; Mayak et al., 2004; Pereyra et al., 2006; Sandhya et al., 2010; Saravanakumar et al., 2011). A review of literature reveals that there is no much investigation in relation to drought acclimation of lettuce treated with PGPR in lettuce. Therefore, this study was undertaken to determine the effects of PGPR on some physiological characteristics, plant growth, yield, and plant nutrient content of lettuce grown under different irrigation levels.

\section{Material and Methods}

Climate of the experimental site and soil properties. Field experiments in 2012 and 2013 were conducted at the Research Station in Ataturk University, Erzurum (39.933 ${ }^{\circ} \mathrm{N}$, $41.236^{\circ} \mathrm{E}$; $1794 \mathrm{~m}$ above sea level), Turkey. Experimental area has semiarid climate due to $404.9 \mathrm{~mm}$ average yearly precipitation according to 1971-2013 period data. In 2012 lettuce growing period (20 July-6 Sept.), average temperature, relative humidity, wind speed, daily sunshine, total evaporation, and precipitation values were $20.0^{\circ} \mathrm{C}$, $49.6 \%, 1.9 \mathrm{~m} \cdot \mathrm{s}^{-1}, 9.4 \mathrm{~h}, 350 \mathrm{~mm}$, and 38.4 $\mathrm{mm}$, respectively. In addition, values of these climatic parameters in growing period (16 Aug.-27 Sept.) of 2013 were $16.1{ }^{\circ} \mathrm{C}, 48.7 \%$, $1.7 \mathrm{~m} \cdot \mathrm{s}^{-1}, 9.5 \mathrm{~h}, 256.6 \mathrm{~mm}$, and $15 \mathrm{~mm}$, respectively. Evaporation and precipitation values were measured in a Class A pan and a pluviometer located in the experimental field, respectively. Other climatic data were obtained from Erzurum meteorological station, which is at a distance of $\approx 5 \mathrm{~km}$ from the experimental field.

According to the U.S. soil taxonomy, the experimental area soils were classified as Aridisol. Some physical and chemical soil properties for layers of $0-30 \mathrm{~cm}$ in experimental area were determined. In lettuce, effective rooting depth $(0-30 \mathrm{~cm})$ with clay loam texture $(28.9 \%$ clay, $35.3 \%$ silt, and $35.8 \%$ sand); the $\mathrm{pH}$; electrical conductivity (EC); plant-available $\mathrm{P}$; exchangeable $\mathrm{Ca}$, $\mathrm{Mg}, \mathrm{K}, \mathrm{Na}$; available Fe, Mn, $\mathrm{Zn}, \mathrm{Cu}, \mathrm{B}$; bulk density; soil moisture contents retained at the $\mathrm{FC}$ and wilting point, and $\mathrm{CaCO}_{3}$; and organic $\mathrm{C}$ contents were $7.63 ; 1.28 \mathrm{dS} \cdot \mathrm{m}^{-1} ; 11$ $\mathrm{mg} \cdot \mathrm{kg}^{-1} ; 22.10 \mathrm{cmolc} \cdot \mathrm{kg}^{-1}, 3.25 \mathrm{cmolc} \cdot \mathrm{kg}^{-1}$, $1.82 \mathrm{cmolc} \cdot \mathrm{kg}^{-1}, \quad 0.14$ cmolc $\cdot \mathrm{kg}^{-1} ; \quad 1.96$ $\mathrm{mg} \cdot \mathrm{kg}^{-1}, 1.38 \mathrm{mg} \cdot \mathrm{kg}^{-1}, 1.46 \mathrm{mg} \cdot \mathrm{kg}^{-1}, 0.81$

Received for publication 26 May 2015. Accepted for publication 10 July 2015 .

We are very grateful to the Atatürk University, Scientific Research Projects Foundation for generous financial support (project number 2012/268).

${ }^{1}$ Corresponding author. E-mail: ertanyil@atauni. edu.tr. $\mathrm{mg} \cdot \mathrm{kg}^{-1}, 0.26 \mathrm{mg} \cdot \mathrm{kg}^{-1} ; 1.33 \mathrm{~g} \cdot \mathrm{cm}^{-3} ; 28.6 \%$ and $16.9 \%$, and $2.28 \%$; and $1.44 \mathrm{~g} \cdot \mathrm{kg}^{-1}$, respectively. Available water holding capacity of the soil is $121.3 \mathrm{~mm}$ in the $0.90 \mathrm{~m}$ soil profile.

Experimental design and bacteria applications to seedlings. The experiment was conducted as split plot based on randomized complete block design with three replications. Three levels of irrigation, $\mathrm{I}_{1}=$ $100 \%$ (control), $\mathrm{I}_{2}=75 \%$, and $\mathrm{I}_{3}=50 \%$ of the FC, were determined at the $0-15 \mathrm{~cm}$ soil depth by TDR, as main plots and three levels of bacterial species consisting of no bacterial inoculation (control), B. megaterium TV $6 \mathrm{D}\left(\mathrm{B}_{1}\right)$, and $B$. subtilis TV $12 \mathrm{H}\left(\mathrm{B}_{2}\right)$ as sub plots. Bacterial strains (B. megaterium TV $6 \mathrm{D}$ and $B$. subtilis TV $12 \mathrm{H}$ ) used in this study were obtained from the culture collection unit in the Department of Plant Protection, Faculty of Agriculture at Atatürk University, Erzurum, Turkey. We selected two potential PGPR from a pool of 460 rhizobacterial isolates based on their ACC deaminasecontaining, auxin (IAA)-producing, $\mathrm{N}_{2}$-fixing, and P-solubilizing strains. The bacterial cultures were grown on nutrient agar for routine use, and maintained in Luria broth with $15 \%$ glycerol at $-80{ }^{\circ} \mathrm{C}$ for long-term storage. In previous studies, these strains were determined to have ability to grow in $\mathrm{N}$-free conditions, solubilize phosphate, produce IAA, SA, and GA (Erman et al., 2010; Kotan et al., 2014; Turan et al., 2014). The PGPR isolates could also grow and produce high amount of amino acid and hormone such as IAA, SA, and GA at the drought stress of $-0.73 \mathrm{MPa}$ created with PEG6000 (data not shown).

Lettuce (Lactuca sativa L. var. longifolia 'Yedikule') seeds were sown into plastic trays filled with peat. Seedlings were initially grown in a greenhouse and then transplanted after $\approx 1$ month in rows on 20 July 2012 and 16 Aug. 2013. Application of the bacterial bio-formulation was performed using the dipping method in which seedling roots were inoculated with the bacterial suspensions in sterile water for about $20 \mathrm{~min}$ before planting. The bacterial suspension $\left(1 \times 10^{8}\right.$ colonyforming units $/ \mathrm{mL}$ ) was included into plastic trays containing $0.2 \mathrm{~g}$ of sucrose (10 $\mathrm{mg} \cdot \mathrm{mL}^{-1}$ ), and seedlings were soaked in this suspension. Additional applications were done $15 \mathrm{~d}$ after transplanting. Bacterial suspensions $\left(10 \mathrm{~L} \cdot \mathrm{ha}^{-1}\right)$ were injected into root zones of the seedlings.

Irrigation applications and plant cultivation. There were no insecticide and fungicide treatments in either experiment. Weeds were kept under control by handweeding. In both years, regular cultural practices were applied uniformly through all plots. Water obtained from the groundwater was used in irrigations. The irrigation water with the $\mathrm{pH}$ value (7.46) close to neutral, and the low EC $\left(0.305 \mathrm{dS} \cdot \mathrm{m}^{-1}\right)$ and the sodium adsorption ratio $(0.52)$ were good quality. The groundwater (irrigation water) stored in a pool was conveyed to the experimental field by a pipeline and applied to the experimental plots by a drip irrigation system. Plots consisted of four rows with $30 \mathrm{~cm}$ apart and were $4.5 \mathrm{~m}$ in length with $30 \mathrm{~cm}$ within-row spacing. There were 27 plots.

A lateral line with the length of $4.5 \mathrm{~m}$ in each row was placed. Polyethylene lateral with in-line type emitters at $0.33 \mathrm{~m}$ emitter distance was $\Phi 16 \mathrm{~mm}$ in diameter. The emitters had a discharge rate of $3.8 \mathrm{~L} \cdot \mathrm{h}^{-1}$ under an operational pressure of $1 \mathrm{~atm}$.

All treatments during seedling planting were irrigated equally, and the current moisture at $0-30 \mathrm{~cm}$ soil depth was reached to the FC in both years. The evaporation amounts from Class A pan was used to determine the amounts of irrigation water applied to three different irrigation treatments $\left(\mathrm{I}_{1}, \mathrm{I}_{2}\right.$, and $\left.\mathrm{I}_{3}\right)$. Irrigations were made every $4 \mathrm{~d}$ during the growing period in trial years. Irrigation water amounts were calculated with below pan evapotranspiration (ET) equation (Ertek, 2011).

$$
\begin{aligned}
& I=E_{\mathrm{p}} \times \mathrm{IR} \times P \\
& P=\left(W_{\mathrm{p}} / W_{\mathrm{r}}\right)
\end{aligned}
$$

where $I$ is the irrigation water amount $(\mathrm{mm}), E_{\mathrm{p}}$ is the cumulative pan evaporation value in planned irrigation interval (mm), IR is the irrigation level (1.0 for the $\mathrm{I}_{1}$ treatment, 0.75 for the $\mathrm{I}_{2}$ treatment, and 0.50 for the $\mathrm{I}_{3}$ treatment), $P$ is the wetting factor, $W_{\mathrm{p}}$ is plant cover width (m), and $W_{\mathrm{r}}$ is plant row spacing (m). The $P$ value changed in the range of $0.30-0.90$ during growing periods in 2012 and 2013.

Crop evapotranspiration $\left(\mathrm{ET}_{\mathrm{c}}\right)$ of lettuce in control plots was calculated using the soil water balance equation (Allen et al., 1998):

$$
\mathrm{ET}_{\mathrm{c}}=I+P+C-D-R \pm \Delta \mathrm{S}
$$

where $\mathrm{ET}_{\mathrm{c}}$ is the crop evapotranspiration, $I$ is the irrigation quantity, $P$ is the precipitation, $C$ is the capillary rise, $D$ is the deep percolation, $R$ is the surface runoff, and $\Delta \mathrm{S}$ is the change in the root zone soil moisture content. The unit of all parameters in the soil water balance equation is millimeter ( $\mathrm{mm})$. Capillary rise from groundwater did not occur due to deep groundwater level $(>20 \mathrm{~m})$. The amount of water from irrigation or precipitation above FC in root zone $(0-30 \mathrm{~cm})$ was considered deep percolation. No runoff was observed during the experiments due to controlled irrigation. Soil moisture measurements for the determining of the $\Delta \mathrm{S}$ were made gravimetrically in soil layers of $0-30$ and $30-60 \mathrm{~cm}$ during the growing period and harvesting, respectively.

Irrigation water use efficiency (IWUE) $\left(\mathrm{kg} \cdot \mathrm{m}^{-3}\right)$ was calculated by dividing the total lettuce fresh yield $\left(\mathrm{g} \cdot \mathrm{m}^{-2}\right)$ by the amount of seasonal irrigation water $(\mathrm{mm})$ (Howell, 2001).

Leaf chlorophyll reading value. The leaf greenness of the lettuce plants was determined by a portable chlorophyll meter (SPAD-502; Konica Minolta Sensing, Inc., Osaka, Japan).

Stomatal conductance. A porometer (Sc-1 Porometer; Decagon Devices Inc., Pullman, 
WA) was used to measure $\mathrm{SC}\left[\mathrm{mmol}\left(\mathrm{H}_{2} \mathrm{O}\right)\right.$. $\mathrm{m}^{-2} \cdot \mathrm{s}^{-1}$ ] on the youngest fully expanded upper leaf, along the right abaxial side of the leaf lamina between 10:00 and 11:00 AM.

Measurement of EL. Ten leaf discs (10 mm in diameter) from fully expanded for the measurement of EL was put in 50-mL glass vials. Vials were then filled with $30 \mathrm{~mL}$ distilled water and allowed to stand in the dark for $24 \mathrm{~h}$ at room temperature. The EC (EC1) of the bathing solution was obtained at the end of the incubation period. Vials were heated in a temperaturecontrolled water bath at $95{ }^{\circ} \mathrm{C}$ for $20 \mathrm{~min}$ and then cooled to room temperature and the $\mathrm{EC}$ (EC2) was measured. Electrolyte leakage was calculated as a percentage of EC1/EC2.

Leaf relative water content. LRWC was measured according to Gonzalez and Gonzalez-Vilar (2001). The young fully expanded leaves were first removed from stem and immediately weighed to determine the fresh weight $(\mathrm{FW})$. Leaves were then floated in distilled water inside a closed petri dish to determine the turgid weight (TW). At the end of the imbibition periods when a steady state was achieved, leaves were placed in an oven at $70^{\circ} \mathrm{C}$ for $48 \mathrm{~h}$ to obtain dry weight (DW). Values of $\mathrm{FW}$, TW, and DW were used to determine the LRWC using the following equation:

$$
\operatorname{LRWC}(\%)=\frac{\mathrm{FW}-\mathrm{DW}}{\mathrm{TW}-\mathrm{DW}} \times 100
$$

Lipid peroxidation (measurement of $M D A$ ). Lipid peroxidation was estimated by determining the MDA contents according to the method of Du and Bramlage (1992).

Mineral analysis. Samples of the lettuce plant leaves were dried at $68^{\circ} \mathrm{C}$ for $48 \mathrm{~h}$ in an oven and then ground. To determine the total $\mathrm{N}$, Kjeldahl method was used with a Vapodest 10 Rapid Kjeldahl Distillation Unit (Gerhardt, Konigswinter, Germany) (Bremner, 1996). An inductively coupled plasma spectrophotometer (Optima 2100 DV, ICP/OES; Perkin-Elmer, Shelton, CT) was used to determine tissue $\mathrm{P}, \mathrm{K}, \mathrm{Ca}, \mathrm{Mg}, \mathrm{Na}, \mathrm{Fe}, \mathrm{Mn}, \mathrm{Zn}$, $\mathrm{Cu}$, and $\mathrm{B}$ (Mertens, 2005).

Growth parameters. Forty-nine and fortythree days after planting in 2012 and 2013, 10 plants from each replicate were randomly harvested, and data on plant growth variables such as head FW, head DW, stem diameter, and head height were collected. The plant material for DW was dried at $70^{\circ} \mathrm{C}$ for $48 \mathrm{~h}$.

Statistical analysis. The SPSS program was used to evaluate the data (SPSS, 2010). The experimental design was hierarchical with respect to two factors arranged in a split plot based on randomized complete block design with three replications. Data were subjected to analysis of variance to compare the effects of irrigation levels and PGPR treatments. The differences among the means were compared using the least significant difference test $(P<$ $0.05)$.

\section{Results}

Irrigation quantity and ET. The seasonal irrigation quantities applied to the $\mathrm{I}_{1}, \mathrm{I}_{2}$, and
$\mathrm{I}_{3}$ treatments were $162.8,122.2$, and $81.4 \mathrm{~mm}$ in 2012 growing period and 128.2, 96.1, and $64.2 \mathrm{~mm}$ in 2013 growing period, respectively. Lower evaporation in 2013 caused lower water applications compared with 2012. Seasonal ET $\left(\mathrm{ET}_{\mathrm{c}}\right)$ values of lettuce in control plots in 2012 were 212.2, 186.9, and $156.8 \mathrm{~mm}$ in the $\mathrm{I}_{1}, \mathrm{I}_{2}$, and $\mathrm{I}_{3}$ treatments, respectively. The $\mathrm{ET}_{\mathrm{c}}$ values in 2013 were also $147.5 \mathrm{~mm}$ in the $\mathrm{I}_{1}, 128.0 \mathrm{~mm}$ in the $\mathrm{I}_{2}$, and $107.8 \mathrm{~mm}$ in the $\mathrm{I}_{3}$. The irrigation water compensation for crop water consumption (Irc) in 2012 was 0.77 in the $\mathrm{I}_{1}, 0.65$ in the $\mathrm{I}_{2}$, and 0.52 in the $\mathrm{I}_{3}$. In addition, these values in 2013 year were $0.87,0.75$, and 0.60 in the $I_{1}$, $\mathrm{I}_{2}$, and $\mathrm{I}_{3}$, respectively. Initial soil moisture during seedling planting for all treatments was at FC in both years. Therefore, high water stress in lettuce plants was appeared under low-Irc conditions.

Growth, yield, water-yield relationship, and IWUE. Irrigation levels and PGPR treatments significantly $(P<0.05)$ affected the growth of lettuce (Table 1). Head FW, head DW, head height, and stem diameter of lettuce plants were lower at $I_{2}$ and $I_{3}$ irrigation levels as compared with $\mathrm{I}_{1}$. However, PGPR applications improved these parameters at lower irrigation levels compared with control (no PGPR inoculation). The highest head FW and DW, head height, and stem diameter were recorded in PGPR inoculated plants in all irrigation treatments.

Yield of lettuce in 2012 was significantly $(P<0.05)$ higher than the yield in 2013 . Moreover, yield was significantly $(P<0.05)$ affected with PGPR treatments and irrigation quantities in both years. Decreasing irrigation quantities significantly $(P<0.05)$ decreased the lettuce yield in both years (Table 1). Yield were decreased linearly with reducing irrigation quantities (Fig. 1). However, the linear relationship equations obtained were not significant. In addition, significant nonlinear relationships could not be observed. PGPR treatments significantly increased the yield compared with control (no PGPR inoculation) under both well-watered and water deficit conditions in both years (Table 1). The $\mathrm{B}_{1}$ bacteria application provided the highest yield values in both years regardless of the irrigation treatments (Table 1). The yield values in $B_{1}$ were $18.1 \%$ and $12.1 \%$ higher than the values of control treatment in 2012 and 2013, respectively. The $I_{1}$ treatment in the $\mathrm{B}_{1}$ and $\mathrm{B}_{2}$ bacteria applications had higher fresh yield values by $18.5 \%$ and $21.0 \%$, respectively, compared with the value of $\mathrm{I}_{1}$ treatment in the control.

Significantly higher IWUE values were determined in 2012 compared with 2013 (Fig. 2). It could be said that higher yield values in 2012 provided higher IWUE values. As shown in Fig. 2, the IWUE values were significantly $(P<0.05)$ higher in the $\mathrm{B}_{1}$ bacterial treatment compared with the control in 2012. In addition, the $I_{3}$ irrigation treatment provided higher IWUE values compared with the $I_{1}$ and $I_{2}$ irrigation treatments. When considering the bacteria and irrigation treatments together, the $\mathrm{I}_{3}$ treatment had the highest IWUE value $\left(71.4 \mathrm{~kg} \cdot \mathrm{m}^{-3}\right.$ in 2012 and $35.0 \mathrm{~kg} \cdot \mathrm{m}^{-3}$ in 2013) under the $B_{1}$ bacteria application conditions. The IWUE value in $\mathrm{I}_{3}$ treatment under the $\mathrm{B}_{1}$ bacteria application conditions in 2012 and 2013 trial years was by $16.9 \%$ and $17.9 \%$ higher than the value in $\mathrm{I}_{3}$ treatment in the control, respectively.

Plant nutrient element content. The concentrations of plant nutrient elements in the leaves of lettuce in response to PGPR and irrigation treatments of each year are shown in Table 2. Statistical analysis showed significant differences among PGPR and irrigation treatments for macro and micro nutrient contents of the plants except $\mathrm{Na}$ content. Macro and micro nutrient contents of lettuce in 2012 were significantly $(P<0.05)$ higher than the nutrient contents of lettuce in 2013 (Table 2). Plant nutrient content of lettuce leaves generally decreased with the decreasing irrigation level; however, PGPR inoculations improved plant nutrient content under lower irrigation levels. The highest $\mathrm{K}, \mathrm{P}, \mathrm{Mn}$, $\mathrm{Zn}, \mathrm{B}$, and $\mathrm{Fe}$ concentrations were obtained from $\mathrm{B}_{1}$ treatment whereas $\mathrm{N}, \mathrm{Ca}$, and $\mathrm{Mg}$ from $B_{2}$ in 2012. In 2013, the highest $P, M n$, $\mathrm{B}, \mathrm{Fe}$, and $\mathrm{Zn}$ concentrations were determined in $\mathrm{B}_{1}$ treatment while $\mathrm{K}, \mathrm{Ca}, \mathrm{Mg}$, and $\mathrm{Cu}$ were determined in $\mathrm{B}_{2}$.

$M D A, S C, L R W C, L C R V$, and EL. PGPR applications and irrigation quantities significantly $(P<0.05)$ affected some physiological properties such as MDA, EL, LRWC, and SC of lettuce (Fig. 3). Lower irrigation levels caused a decrease in LRWC and SC but an increase in MDA and EL. However, PGPR inoculations significantly increased LRWC and $\mathrm{SC}$, and decreased EL and MDA of the lettuce plants grown under lower irrigation levels. Leaf chlorophyll reading value (LCRV) was affected by neither irrigation levels nor PGPR applications. $\mathrm{B}_{1}$ and $\mathrm{B}_{2}$ applications at $\mathrm{I}_{3}$ increased LRWC by $10.0 \%$ and $13 \%$ in $2012,15.0 \%$ and $9 \%$ in 2013 , respectively, as compared with control. Similarly, $S C$ values at $\mathrm{I}_{3}$ were raised by $\mathrm{B}_{1}$ and $\mathrm{B}_{2}$ applications at the ratio of $19 \%$ and $45 \%$ in 2012 and $46 \%$ and $41 \%$ in 2013 , respectively, when compared with control. The lowest values of EL were obtained from $\mathrm{B}_{1}$ while MDA from $B_{2}$ at $I_{3}$.

\section{Discussion}

Seasonal $\mathrm{ET}_{\mathrm{c}}$ values of lettuce in 2012 were higher than those in 2013. Higher ET values in 2012 could be explained with higher air temperatures and longer growing periods compared with 2013. Average air temperature was $20{ }^{\circ} \mathrm{C}$ during growing period in 2012 and $16.1{ }^{\circ} \mathrm{C}$ during 2013 growing period. Moreover, total growing period in 2012 and 2013 were 49 and 43 d, respectively. Some researchers determined similar ET values with our results. Kuslu et al. (2008) found average $232.3 \mathrm{~mm}$ ET value for fully irrigated curly lettuce in Erzurum, Turkey. Kadayifci et al. (2004) obtained that ET of fully irrigated lettuce was $285 \mathrm{~mm}$ under greenhouse conditions. 
Table 1. Yield and growth characteristics of lettuce plants in response to plant growth-promoting rhizobacteria (PGPR) treatments under different irrigation levels. $^{z}$

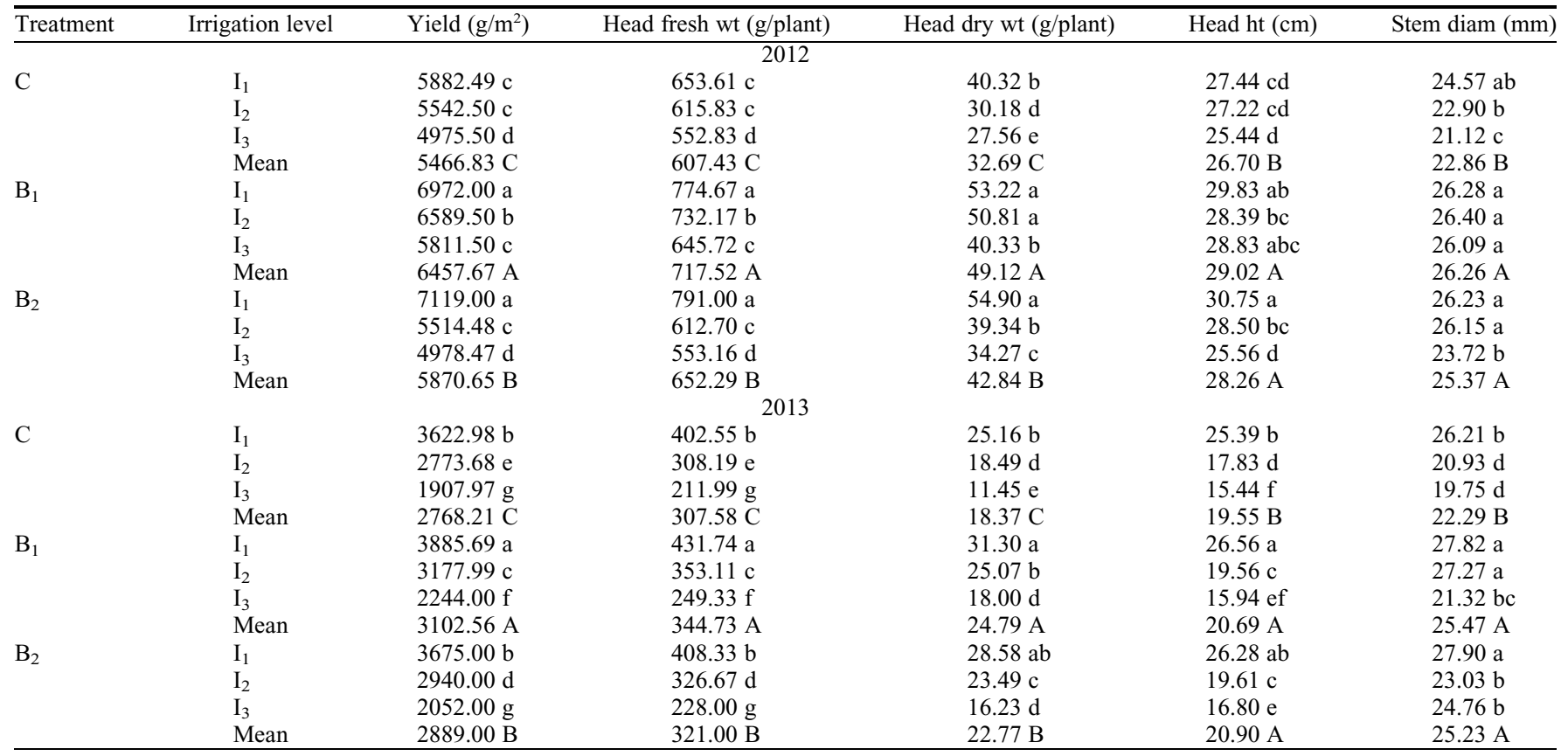

${ }_{\mathrm{z}}$ Means are separated within each column by least significant difference test at $P<0.05$ for each year.

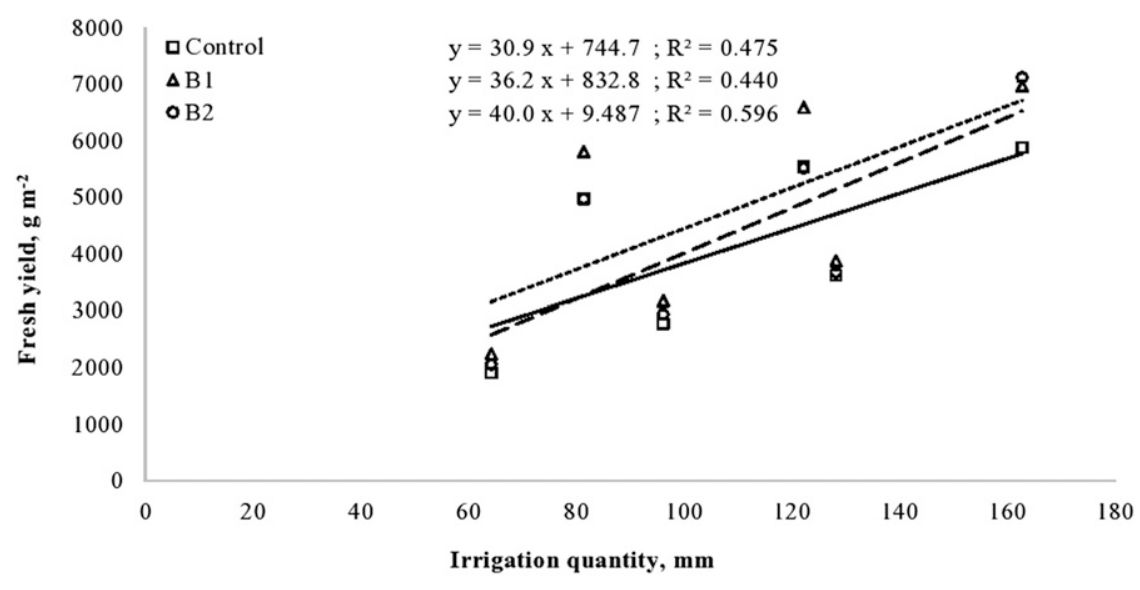

Fig. 1. The relationships between fresh yield of lettuce and deficit irrigation quantity during different bacterial application conditions.

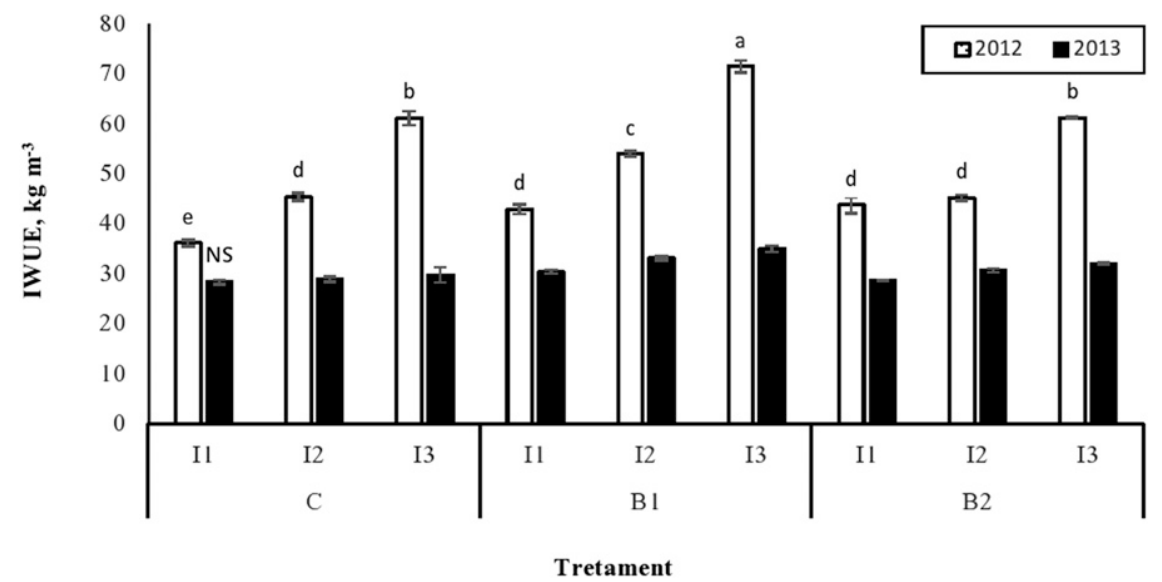

Fig. 2. Irrigation water use efficiency (IWUE) values of lettuce plants in response to plant growthpromoting rhizobacteria (PGPR) treatments under different irrigation levels. Different letters on top of bars indicate differences (least significant difference test, $P<0.05$ ). Mean separation within each year. NS $=$ nonsignificant.
Oliveira et al. (2005) determined a $117 \mathrm{~mm}$ average water use for head lettuce irrigated with subsurface drip system.

The highest yield values were obtained from the $I_{1}$ regardless of PGPR treatments. The yield values in the $I_{1}$ treatment as average of all treatments were $6657.8 \mathrm{~g} \cdot \mathrm{m}^{-2}$ in 2012 and $3727.9 \mathrm{~g} \cdot \mathrm{m}^{-2}$ in 2013. The $\mathrm{I}_{2}$ and $\mathrm{I}_{3}$ treatments provided lower yields by $11.7 \%$ and $21.1 \%$ in 2012 and $20.5 \%$ and $44.5 \%$ in 2013 , respectively, compared with the $I_{1}$ treatment. Our results were similar to those of Kadayifci et al. (2004), Kuslu et al. (2008), and Yazgan et al. (2008), who determined that lettuce yield significantly decreased with reducing water applications. Lower irrigation levels negatively affected the plant growth parameters such as head FW, head DW, plant height, and stem diameter of lettuce. Water deficit negatively influences the plant growth by changing a series of morphological, physiological, and metabolic processes and reduces the yield of plant (Fard et al., 2011). Lipiec et al. (2013) reported that drought stress resulted in reduced accumulation in plant mass, shorter first internode, increased tillering, early senescence and premature death, and fruit discoloration and damage in various plants.

The results of the study showed that yield and growth were significantly increased by PGPR inoculations under lower and wellwatered conditions, and PGPR inoculations could alleviate the deleterious effect of drought stress on the growth and yield of lettuce. The highest growth parameters investigated and yield were obtained from $B_{1}$ (B. megaterium TV 6D) treatment in both years. Our findings are similar with earlier studies showing that PGPR inoculations could improve the yield and growth of different crops grown under drought stress (Arkhipova 


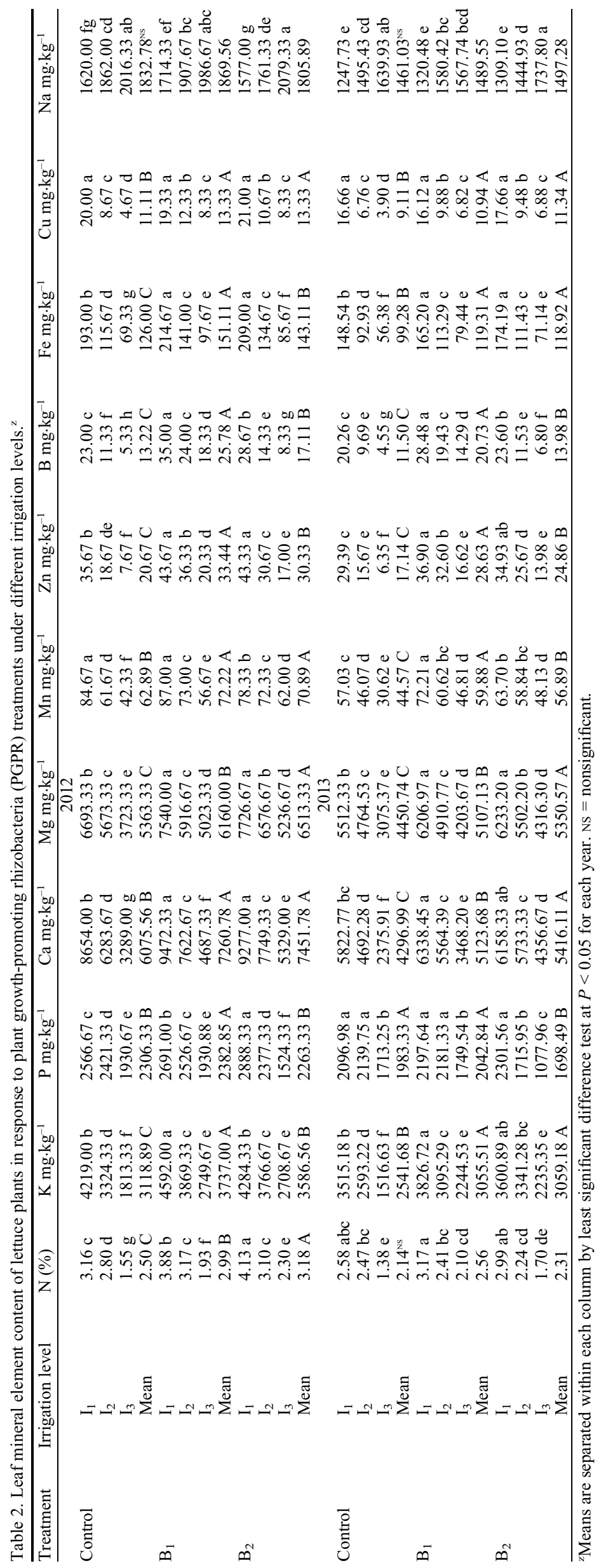

et al., 2007; Gururani et al., 2013; Heidari and Golpayegani, 2012; Marcinska et al., 2013; Saravanakumar et al., 2011). PGPR have been reported to have the potential of the amelioration of deleterious effects caused by drought stress in crops (Hayat et al., 2010; Mayak et al., 2004). Recent researches on PGPR revealed that they could enhance the plant growth under stress conditions by producing ACC deaminase (Dey et al., 2004), generating plant growth regulators such as IAA (Turan et al., 2014), GA (Narula et al., 2006), and cytokinins (Ortíz-Castro et al., 2008). In addition, they can fix asymbiotic nitrogen (Ardakani et al., 2010) and help in the solubilization of "mineral phosphates" and other nutrient elements (Hayat et al., 2010). Similarly, PGPR strains used in the study have been shown to produce ACC deaminase, to have capability to grow in $\mathrm{N}$-free conditions, solubilize phosphate, and produce IAA, SA, and GA (Erman et al., 2010; Kotan et al., 2014; Turan et al., 2014).

Irrigation levels and PGPR applications significantly affected IWUE values in 2012 while interaction was not significant in 2013. $\mathrm{I}_{3}$ irrigation treatment increased IWUE values compared with the $\mathrm{I}_{1}$ and $\mathrm{I}_{2}$ irrigation treatments in all PGPR treatments (Fig. 2). While some previous studies indicated that IWUE values were generally higher under lower irrigation conditions (Bozkurt et al., 2009; Kuslu et al., 2008), some of them also indicated that IWUE values decreased with lower water applications (Bozkurt and Mansuroglu, 2011; Kadayifci et al., 2004). PGPR treatments positively affected IWUE values at all irrigation levels in 2012. In addition, $\mathrm{B}_{1}$ provided higher IWUE values than other PGPR applications. Earlier studies suggested that PGPR could improve drought tolerance and water use efficiency of plants under water deficit conditions (Marulanda et al., 2009; Sandhya et al., 2010). PGPR have been reported to facilitate the rooting and growth of plants grown under drought stress by improving the water use efficiency (Mayak et al., 2004). The ET values of lettuce in 2013 were lower than the values in 2012.

Results of the study indicated that irrigation levels had a significant effect $(P<0.05)$ on some physiological characteristics of lettuce (Fig. 3). In our study, lower irrigation levels significantly decreased LRWC and SC, and significantly increased MDA and EL in lettuce. Leaf water content and gas exchange are physiological processes very susceptible to drought stress (Marcinska et al., 2013). The stomatal closure to reduce the water loss in leaves is one of the changes in plants grown under drought stress (Farooq et al., 2009). Previous studies indicated that the photosynthesis rate and transpiration were substantially lower under water deficit than under well-watered conditions. The decline in the photosynthetic rate under drought stress is frequently attributed to lower internal $\mathrm{CO}_{2}$, inhibition of photosynthetic enzymes (e.g., rubisco) and synthesis of adenosine triphosphate (Lipiec et al., 2013). Drought stress can cause the reduction of 

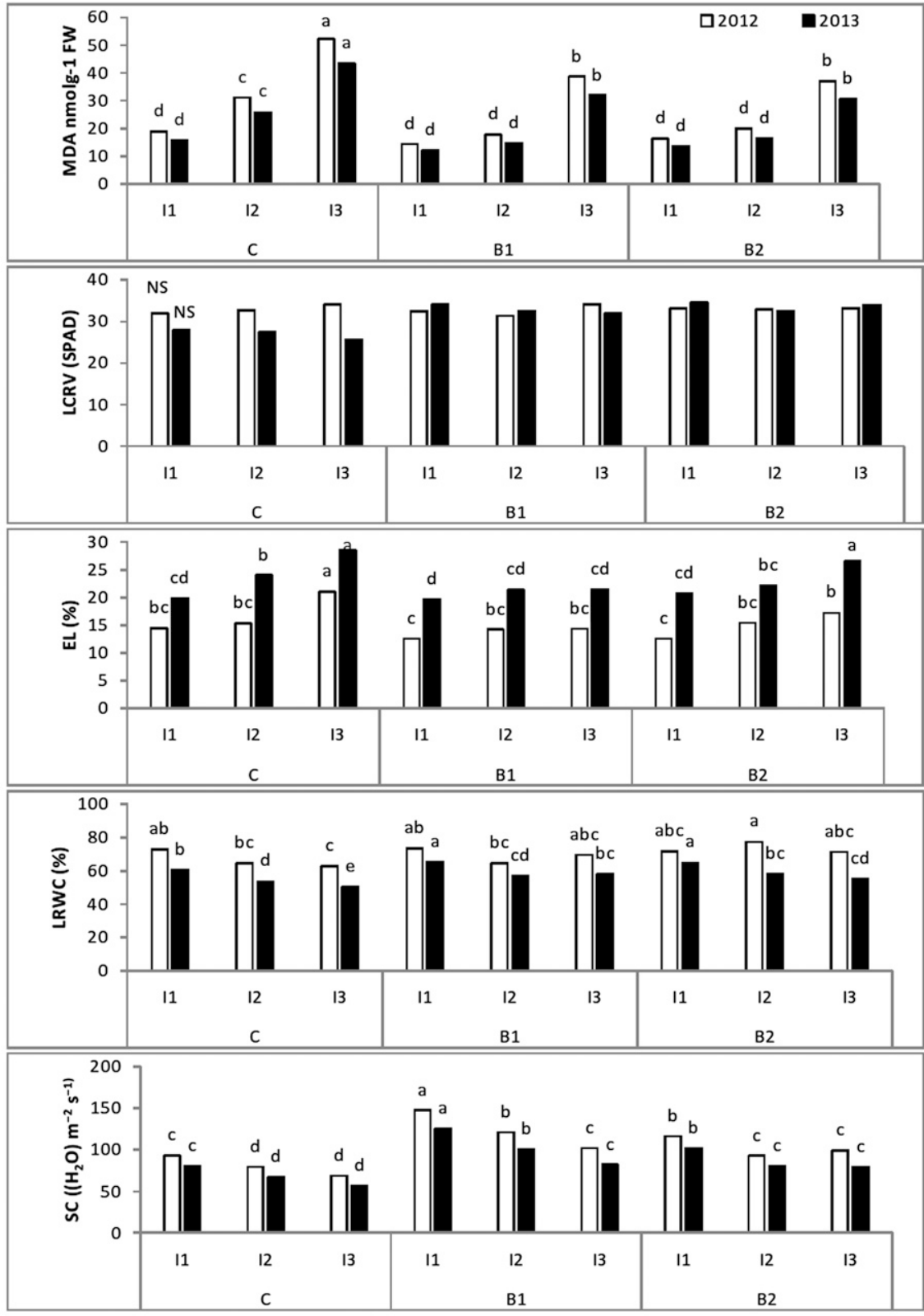

Fig. 3. Malondialdehyde (MDA), leaf chlorophyll reading value (LCRV), electrolyte leakage (EL), leaf relative water content (LRWC), and stomatal conductance (SC) values of lettuce plants in response to plant growth-promoting rhizobacteria (PGPR) treatments under different irrigation levels. Different letters on top of bars indicate differences (least significant difference test, $P<0.05$ ). Mean separation within each year. $\mathrm{NS}=$ nonsignificant.

water content, turgor, total water potential, wilting, closure of stomata, and the decrease in cell enlargement and growth. Severe water stress may result in arrest of photosynthesis, disturbance of metabolism, and finally death (Jaleel et al., 2008). Drought stress has been reported to stimulate production of ROS, causing membrane injuries, protein degradation, enzyme inactivation, and thus induce oxidative stress (Liu and Huang, 2000; Zlatev and Lidon, 2012).

PGPR inoculations significantly $(P<0.05)$ increased LRWC and SC, and decreased MDA and EL values under lower irrigation levels. $B_{1}$ and $B_{2}$ treatments generally had greater LRWC and SC values compared with control (no bacterial inoculation) (Fig. 3).
Elevated LRWC values by PGPR inoculations have been reported for tomatoes and peppers (Mayak et al., 2004), maize (Marulanda et al., 2009) and strawberry (Karlidag et al., 2011) grown under osmotic stress. It was reported that PGPR inoculations could enhance plant tolerance to drought by increasing their water content, which can be attributed to the enhancement of root growth because of IAA produced by bacteria (Marulanda et al., 2009). High LRWC has been suggested as a preferential mechanism for stress tolerance (Merah, 2001).

Present results showed the cellular damages, as indicated by the increases in MDA, and membrane permeability (Fig. 3). The observed increases in the MDA content and
EL of lettuce leaves are similar to previous results reported by Bai et al. (2006) who stated that an increase of MDA and EL of plants grown under drought stress indicated oxidative damage to plants, which means lipid peroxidation may be a consequence of generation of reactive oxygen species. The increase of lipid peroxidation (MDA) could cause disorder and damage of the membrane system, and that a decrease in photosynthesis and respiration resulting from a damaged ultrastructure was the physiological factor resulting in decreased yield (Bai et al., 2006).

There is evidence that antioxidant enzymes can eliminate free radicals and protect damage to membranes from stress conditions (Scandalios, 1994). Some PGPR strains have been reported to elevate the levels of such enzymes in plants, which ameliorate the deleterious effects of drought stress (Kohler et al., 2008). Previous studies indicated that PGPR-inoculated plants had higher stomatal conductance values than that of noninoculated ones under drought stress (Liu et al., 2013). We used ACC deaminase-containing PGPR strains in the study. The ACC deaminase degrades the ethylene precursor ACC to $\alpha$-ketobutyrate and ammonia, which helps the plant cells from desiccation under drought stress (Glick, 2005).

PGPR applications and irrigation quantities significantly affected nutrient content. Lower irrigation levels caused a decreased nutrient content except $\mathrm{Na}$ content while PGPR inoculations increased generally their concentrations in lettuce compared with control (Table 2). Plants grown under drought stress can accumulate some ions such as $\mathrm{Na}$ and some organic and amino acids to avoid deleterious effects of abiotic stress conditions. It has been reported that root cationexchange capacity and nutrient uptake in dry environments could be significantly reduced, and the relative uptake of polyvalent cations might induce additional toxicity (Lukowska and Józefaciuk, 2013). PGPR might increase the nutrient uptake from soils, thus reducing the need for fertilizers and preventing the accumulation of nitrates and phosphates in agricultural soils (Yang et al., 2009). Yildirim et al. (2006) reported that PGPR inoculations lowered the Na content and elevated $\mathrm{K}$ and $\mathrm{Ca}$ contents compared with the control in squash grown under salinity stress. Kloepper et al. (2007) pointed out that PGPR could improve the roots by producing phytohormones such as IAA, thus could increase the mineral element uptake and promote plant development. Promotion of root growth results in a larger root surface, and can, therefore, has positive effects on water acquisition and nutrient uptake (Dimkpa et al., 2009). In our study, nitrogen fixation ability of PGPR could have been one of the main factors improving nutrient uptake and growth of lettuce. In addition, solubilization of phosphorus and production of hormones such as IAA, SA, and GA may have positive effect on nutrient uptake and growth of lettuce. Turan et al. (2014) suggested that PGPR treatments could affect root hormone levels 
by producing plant hormones such as IAA in the rhizosphere, which were then absorbed by the root.

PGPR strains used in this study produced amino acid and hormone and were capable to survive under drought stress condition created with PEG6000. This research reveals that PGPR, which has high tolerance capability against drought stress, can be used for reducing the deleterious effects of drought conditions on yield and growth of lettuce. PGPR inoculations can be used as a good tool in the enhancement of growth and yield in plants and can be used as an agent in water deficit stress amelioration as an eco-friendly approach. B. megaterium TV $6 \mathrm{D}\left(\mathrm{B}_{1}\right)$ treatment can especially be suggested for more yield and irrigation water use efficiency (IWUE) in lettuce growing under lower irrigation levels. In the future, we plan to prepare a commercial preparation after making a good carrier consist of organic material with long shelf life for the most effective bacterial strain.

\section{Literature Cited}

Allen, R.G., L.S. Pereira, D. Raes, and M. Smith. 1998. Crop evapotranspiration: Guidelines for computing crop water requirements. FAO Irrigation and Drainage Paper No: 56. FAO, Rome.

Ardakani, S.S., A. Heydari, L. Tayebi, and M. Mohammedi. 2010. Promotion of cotton seedlings growth characteristics by development and use of new bioformulations. Intl. J. Bot. 6(2):95-100.

Arkhipova, T.N., E. Prinsen, S.U. Veselov, E.V. Martinenko, A.I. Melentiev, and G.R. Kudoyarova. 2007. Cytokinin producing bacteria enhance plant growth in drying soil. Plant Soil 292:305-315.

Athar, H.R. and M. Ashraf. 2009. Strategies for crop improvement against salinity and drought stress: An overview, p. 1-16. In: M. Ashraf, M. Ozturk, and H.R. Athar (eds.). Salinity and water stress: Improving crop efficiency. Springer, Netherlands.

Bai, L., F. Sui, T. Ge, Z. Sun, Y. Lu, and G. Zhou. 2006. Effect of soil drought stress on leaf water status, membrane permeability and enzymatic antioxidant system of maize. Pedosphere 16(3): 326-332.

Blum, B. 2011. Drought resistance-is it really a complex trait? Funct. Plant Biol. 38:753-757.

Bozkurt, S. and G.S. Mansuroglu. 2011. Lettuce yield responses to different drip irrigation levels under open field condition. J. Cell and Plant Sci. 2:12-18.

Bozkurt, S., G.S. Mansuroğlu, M. Kara, and S. Onder. 2009. Responses of lettuce to irrigation levels and nitrogen forms. Afr. J. Agr. Res. 4:1171-1177.

Bremner, J.M. 1996. Nitrogen-total, p. 1085-1122. In: D.L. Sparks (ed.). Methods of soil analysis: Part III, chemical methods. 2nd ed. Soil Sci. Soc. Amer., Madison, WI.

Dey, R., K.K. Pal, D.M. Bhatt, and S.M. Chaunhan. 2004. Growth Promotion and yield enhancement of peanut (Arachis hypogaea L.) by application of plant growth-4 promoting rhizobacteria. Microbiol. Res. 159:371-394.

Dimkpa, C., T. Weinand, and F. Asch. 2009. Plant-rhizobacteria interactions alleviate abiotic stress conditions. Plant Cell Environ. 32:1682-1694.
Du, Z. and W.J. Bramlage. 1992. Modified thiobarbituric acid assay for measuring lipid oxidation in sugar-rich plant tissue extracts. J. Agr. Food Chem. 40:1566-1570.

Erman, M., R. Kotan, R. Çakmakçı, F. Çı̆̆, K. Karagöz, and M. Sezen. 2010. Effect of nitrogen fixing and phosphate-solubilizing Rhizobacteria isolated from Van Lake Basin on the growth and quality properties in wheat and sugar beet, p. 325-329. In: Turkey IV. Organic farming symposium, 28 June-1 July 2010, Erzurum, Turkey.

Ertek, A. 2011. Importance of pan evaporation for irrigation scheduling and proper use of croppan coefficient (Kcp), crop coefficient $(\mathrm{Kc})$ and pan coefficient (Kp). Afr. J. Agr. Res. 6:6706-6718

Fard, F.D., D. Habibi, and M.D. Fard. 2011. Effect of plant growth promoting rhizobacteria and foliar application of amino acids and salicylic acid on biochemical biomarkers activity of wheat under drought stress. 2nd International Conference on Chemical Engineering and Applications IPCBEE vol. 23 (2011) IACSIT Press, Singapore.

Farooq, M., A. Wahid, N. Kobayashi, D. Fujita, and S.M.A. Basra. 2009. Plant drought stress: Effects, mechanisms and management. Agron. Sustain. Dev. 29:185-212.

Forchetti, G., O. Masciarelli, M.J. Izaguirre, S. Alemano, D. Alvarez, and G. Abdala. 2010. Endophytic bacteria improve seedling growth of sunflower under water stress, produce salicylic acid, and inhibit growth of pathogenic fungi. Curr. Microbiol. 61:485-493.

Glick, B.R. 1995. The enhancement of plant growth by freeliving bacteria. Can. J. Microbiol. 41:109-117.

Glick, B.R. 2005. Modulation of plant ethylene levels by the bacterial enzyme ACC deaminase. FEMS Microbiol. Lett. 251:1-7.

Gonzalez, L. and M. Gonzalez-Vilar. 2001. Determination of relative water content. In: M.J. Reigosa (ed.). Handbook of plant ecophysiology techniques, p. 207-212. Kluwer Academic Publishers, Dordrecht, the Netherlands.

Gururani, M.A., C.P. Upadhyaya, V. Baskar, J. Venkatesh, A. Nookaraju, and S.W. Park. 2013. Plant growth-promoting rhizobacteria enhance abiotic stress tolerance in Solanum tuberosum through inducing changes in the expression of ROS-scavenging enzymes and improved photosynthetic performance. J. Plant Growth Regulat. 32:245-258.

Hayat, R., S. Ali, U. Amara, R. Khalid, and I. Ahmed. 2010. Soil beneficial bacteria and their role in plant growth promotion: A review. Ann. Microbiol. 60:579-598.

Heidari, M. and A. Golpayegani. 2012. Effects of water stress and inoculation with plant growth promoting rhizobacteria (PGPR) on antioxidant status and photosynthetic pigments in basil (Ocimum basilicum L.). J. Saudi Soc. Agr. Sci. 11:57-61.

Henry, N. and Le. Hou'erou. 1996. Climate change, drought and desertification. J. Arid Environ. 34:133-185.

Howell, T.A. 2001. Enhancing water use efficiency in irrigated agriculture. Agron. J. 93:281-289.

Jaleel, C.A., P. Manivannan, G.M.A. Lakshmanan, M. Gomathinayagam, and R. Panneerselvam. 2008. Alterations in morphological parameters and photosynthetic pigment responses of Catharanthus roseus under soil water deficits. Colloids Surf. B Biointerfaces 61:298-303.

Kadayifci, A., G.I. Tuylu, Y. Ucar, and B. Cakmak. 2004. Effects of mulch and irrigation water amounts on lettuce's yield, evapotranspiration, transpiration and soil evaporation in Isparta location. Turkey J. Biol. Sci. 4:751-755.

Karlidag, H., A. Esitken, E. Yildirim, M.F. Donmez, and M. Turan. 2011. Effects of plant growth promoting bacteria (PGPB) on yield, growth, leaf water content, membrane permeability and ionic composition of strawberry under saline conditions. J. Plant Nutr. 34(1):34-45.

Kloepper, J.W., A. Gutierrez-Estrada, and J.A. Mclnroy. 2007. Photoperiod regulates elicitation of growth promotion but not induced resistance by plant growth-promoting rhizobacteria. Can. J. Microbiol. 53(2):159-167.

Kohler, A.J., B.J.A. Hernández, F.A.C. Caravaca, and A. Roldá. 2008. Plant-growth-promoting rhizobacteria and arbuscular mycorrhizal fungi modify alleviation biochemical mechanisms in water-stressed plants. Funct. Plant Biol. 35:141-151.

Kotan, R., P. Mohammadi, K. Karagöz, F. Dadaşoğlu, A. Güneş, and E. Tozlu. 2014. Determination of broad spectrum bacterial strains which can be used as biopesticides and biofertilizers in agriculture, p. 313. Turkey V. Plant Ptotection Symposium, 3-5 Feb. 2014, Antalya, Turkey.

Kuslu, Y., A. Dursun, U. Sahin, F.M. Kiziloglu, and M. Turan. 2008. Short communication. Effect of deficit irrigation on curly lettuce grown under semiarid conditions. Span. J. Agr. Res. 6:714 719.

Lipiec, J., C. Doussan, A. Nosalewicz, and K. Kondracka. 2013. Effect of drought and heat stresses on plant growth and yield: A review. Intl. Agrophysics 27:463-477.

Liu, X. and B. Huang. 2000. Heat stress injury in relation to membrane lipid peroxidation in creeping bent grass. Crop Sci. 40:503-510.

Liu, F., S. Xing, H. Ma, Z. Du, and B. Ma. 2013. Cytokinin-producing, plant growth-promoting rhizobacteria that confer resistance to drought stress in Platycladus orientalis container seedlings. Appl. Microbiol. Biotechnol. 97:91559164.

Lukowska, M. and G. Józefaciuk. 2013. Unknown mechanism of plants response to drought: Low soil moisture and osmotic stresses induce severe decrease in CEC and increase in acidity of barley roots. J. Agr. Sci. 5(10):204-213.

Marcinska, I., I. Czyczyło-Mysza, E. Skrzypek, M. Filek, S. Grzesiak, M.T. Grzesiak, F. Janowiak, and M. Hura. 2013. Impact of osmotic stress on physiological and biochemical characteristics in drought-susceptible and drought-resistant wheat genotypes. Acta Physiol. Plant. 35:451-461.

Marulanda, A., J.M. Barea, and R. Azcon. 2009. Stimulation of plant growth and drought tolerance by native microorganisms (AM fungi and bacteria) from dry environments: Mechanisms related to bacterial effectiveness. J. Plant Growth Regulat. 28:115-124.

Mayak, S., T. Tirosh, and B.R. Glick. 2004. Plant growth-promoting bacteria that confer resistance to water stress in tomatoes and peppers. Plant Sci. 166:525-530.

Merah, O. 2001. Potential importance of water status traits for durum wheat improvement under Mediterranean conditions. J. Agr. Res. 137:139-145.

Mertens, D. 2005. Plants preparation of laboratory sample, p. 1-2. In: W. Horwitz and G.W. Latimer (eds.). Official methods of analysis. 18th ed. AOAC, Gaithersburg, MD.

Narula, N., A. Deubel, W. Gans, R.K. Behl, and W. Merbach. 2006. Paranodules and colonization of wheat roots by phytohormone producing bacteria in soil. Plant Soil Environ. 52(3): 119-129. 
Oliveira, A.S., E.C. Martin, D.C. Slack, E.J. Pegelow, and A.D. Folta. 2005. Water use and crop coefficient of subsurface drip-irrigated lettuce in Central Arizona. Rev. Bras. Eng. Agr. Ambient. 9:37-44.

Ortíz-Castro, R., E. Valencia-Cantero, and J. LópezBucio. 2008. Plant growthpromotion by Bacillus megaterium involves cytokinin signaling. Plant Signal. Behav. 3:263-265.

Pereyra, M.A., C.A. Zalazarb, and C.A. Barassia. 2006. Root phospholipids in Azospirilluminoculated wheat seedlings exposed to water stress. Plant Physiol. Biochem. 44:873-879.

Sandhya, V., S.Z. Ali, B. Venkateswarlu, G. Reddy, and M. Grover. 2010. Effect of plant growth promoting Pseudomonas spp. on compatible solutes, antioxidant status and plant growth of maize under drought stress. Plant Growth Regulat. 62:21-30.

Saravanakumar, D., M. Kavino, T. Raguchander, P. Subbian, and R. Samiyappan. 2011. Plant growth promoting bacteria enhance water stress resistance in green gram plants. Acta Physiol. Plant. 33:203-209.

Scandalios, J.G. 1994. Regulation and properties of plant catalases, p. 275-315. In: C.H. Foyer and P.M. Mullineaux (eds.). Causes of photooxidative stress and amelioration of defense systems in plants. CRC Press, Boca Raton, FL.

SPSS Inc. 2010. SPSS ${ }^{\circledR} 18.0$ base user's guide. Prentice Hall.

Turan, M., M. Ekinci, E. Yildirim, A. Gunes, K. Karagoz, R. Kotan, and A. Dursun. 2014. Plant growth promoting rhizobacteria improved growth, nutrient and hormone content of cabbage (Brassica oleracea) seedlings. Turk. J. Agr. For. 38(3):327-333.

Yang, J., J.W. Kloepper, and C.M. Ryu. 2009. Rhizosphere bacteria help plants tolerate abiotic stress. Plant science conferences in 2009. Plant Abiotic Stress Tolerance 8-11 Feb. 2009, Vienna, Austria.

Yazgan, S., S. Ayas, C. Demirtas, H. Büyükcangaz, and B.N. Candogan. 2008. Deficit irrigation effects on lettuce (Lactuca sativa var. Olenka) yield in unheated greenhouse condition. J. Food Agr. Environ. 6:357-361.

Yildirim, E., A.G. Taylor, and T.D. Spittler. 2006. Ameliorative effects of biological treatments on growth of squash plants under salt stress. Sci. Hort. 111(1):1-6.

Yildirim, E., M.F. Donmez, and M. Turan. 2008. Use of bioinoculants in ameliorative effects on radish (Raphanus sativus L.) plants under salinity stress. J. Plant Nutr. 31(12):20592074

Yildirim, E., M. Turan, M. Ekinci, A. Dursun, and R. Cakmakci. 2011. Plant growth promoting rhizobacteria ameliorate deleterious effect of salt stress on lettuce. Sci. Res. Essays 6(20): 4389-4396.

Zlatev, Z. and F.C. Lidon. 2012. An overview on drought induced changes in plant growth, water relations and photosynthesis. Emir. J. Food Agr. 24:57-72. 